University of Chicago Law School

Chicago Unbound

Journal Articles

Faculty Scholarship

2007

\title{
The International Protection of Cultural Property: Some Skeptical Observations
}

Eric A. Posner

Follow this and additional works at: https://chicagounbound.uchicago.edu/journal_articles

Part of the Law Commons

\section{Recommended Citation}

Eric Posner, "The International Protection of Cultural Property: Some Skeptical Observations," 8 Chicago Journal of International Law 213 (2007).

This Article is brought to you for free and open access by the Faculty Scholarship at Chicago Unbound. It has been accepted for inclusion in Journal Articles by an authorized administrator of Chicago Unbound. For more information, please contact unbound@law.uchicago.edu. 


\title{
The International Protection of Cultural Property: Some Skeptical Observations
}

\author{
Eric A. Posner*
}

\section{INTRODUCTION}

Cultural property refers to property that has some special relationship with a particular culture or nation state. Cultural property includes objects found at archeological sites, which provide insight into earlier civilizations, and artworks produced by members of a culture that are thought to embody or represent that culture in a distinctive way. The contours of the definition are vague and shifting, but the controversies over the use of cultural property are real, and raise important problems for domestic and international law.

There are three controversies of importance today. First, a global black market in antiquities exported in violation of the domestic law of origin states is worth billions of dollars. Many of the antiquities are removed from archeological sites in violation of domestic law, exported in violation of domestic law, and then traded in places like Switzerland and the United States, ending up in museums or private collections. Origin states complain that their cultural heritage is being stolen, and archeologists worry that the goods are being removed without attention to their archeological context; they are inadequately stored, recorded, and protected, and ultimately lost to scholarship.'

Second, many antiquities that were not, strictly speaking, stolen or removed in violation of domestic law are of such great cultural value that origin states are demanding their return despite the absence of problems with title. The complaints are thus moral and political, not legal, although often the circumstances under which the goods were obtained are sufficiently murky that a

* Kirkland \& Ellis Professor of Law, The University of Chicago. Thanks to Lior Strahilevitz and participants at a Conference on Cultural Property at the University of Chicago for helpful comments.

1 For discussions, see the essays in Neil Brodie, Jennifer Doole, and Colin Renfrew, eds, Trade in Illicit Antiquities: The Destruction of the World's Archeological Heritage (McDonald Inst 2001). 
claim of theft is made as well. Controversy over whether these goods should be returned to the origin state has added friction to the relations between states. ${ }^{2}$

Third, many antiquities are destroyed during wartime. In the first Gulf War, the US promised not to attack cultural property in Iraq, but ended up destroying some cultural property when Iraq located military assets in archeological sites. ${ }^{3}$ In the second Gulf War, the US failed to prevent looting of museums and archeological sites by criminals and ordinary Iraqi citizens. The looting has resulted in the destruction or disappearance of many antiquities.

The first and third problems have been addressed by international law in the past. The 1970 UNESCO Convention on the Means of Prohibiting and Preventing the Illicit Import, Export and Transfer of Ownership of Cultural Property ("UNESCO Convention") provides, among many other things, that states should respect the export restrictions of origin states. ${ }^{4}$ Thus, if Italy forbids people to export Etruscan objects, parties to the convention are supposed to pass laws that punish people who import Etruscan objects. The general view is that the UNESCO Convention has failed to halt the trade in illegally acquired antiquities, and indeed that this trade is far greater today than it was forty years ago.

The 1954 Hague Convention for the Protection of Cultural Property in the Event of Armed Conflict ("Hague Convention") 5 and its two protocols obligate belligerents to avoid targeting cultural property and to protect it when possible, and it requires states at peace to take certain measures to protect their own cultural property in advance of war. The 1954 Hague Convention is also widely, although not universally, considered a failure. Even putting aside the debacle in Iraq (which is not governed by the convention because the US is not a party), the destruction of cultural property has been a feature of dozens of wars and civil conflicts over the last fifty years.

In this Article, I will argue that both of these legal regimes are misconceived. Both regimes assume that cultural property is distinctive or special, and therefore different from ordinary property; however, it turns out

2 See, for example, John Henry Merryman, Thinking about the Elgin Marbles, 83 Mich L Rev 1881 (1985), reprinted in John Henry Merryman, Thinking about the Elgin Marbles: Critical Essays on Cultural Property, Art and Law 24 (Kluwer 2000).

3 See US Dept of Defense, Conduct of the Persian GulfWar. Final Report to Congress 125-26 (1992).

4 Contention on the Means of Prohibiting and Preventing the Illicity Import, Export and Transfer of Ownership of Cultural Property (Nov 14, 1970), 823 UN Treaty Ser 231 (1972), available online at <http://portal.unesco.org/en/ev.php-URL_ID=13039\&URL_DO=DO_TOPIC\& URL_SECTION=201.html> (visited Apr 21, 2007).

5 Convention for the Protection of Cultural Property in the Event of Armed Conflict May 14, 1954), 249 UN Treaty Ser 240, available online at <http://portal.unesco.org/en/ev.phpURL_ID=13637\&URL_DO=DO_TOPIC\&URL_SECTION=201.html $>$ (visited Apr 21, 2007). 
that it is hard to make sense of this assumption. There is no good argument for international legal regulation of cultural property, during peacetime or wartime. I argue that the UNESCO Convention likely has perverse effects and that the treatment of cultural property would improve, even during wartime, if the current regime of international regulation were abolished. ${ }^{6}$

\section{THE TREATY REGIME}

\section{A. International Law of Cultural Property}

\section{The Law of Armed Conflict}

The laws of war-or international humanitarian law-go back centuries, but their modern incarnation is conventionally dated to the Hague Peace Conferences of 1899 and 1907. The Fourth Hague Convention prohibited belligerents from targeting or intentionally damaging "buildings dedicated to religion, art, science, or charitable purposes, [and] historic monuments" ${ }^{\prime 7}$ or seizing or intentionally damaging "institutions dedicated to religion, charity and education, the arts and the sciences, ... historic monuments, [and] works of art and science," These rules failed to prevent destruction and looting of cultural property on a massive scale during World War I and World War II.

It should be noted that the Hague Conventions also codified the longstanding doctrine that belligerent forces should not intentionally damage or seize private property or state property that does not have a military purpose. Thus, the Fourth Hague Convention clarified that cultural property was governed by this doctrine.

In an effort to strengthen the laws protecting cultural property in the wake of their disastrous failure in World War II, states sent delegates to another Hague conference in 1954, and the result was the Hague Convention. ${ }^{9}$ Its main provisions established that (i) the parties would prepare for armed conflicts by taking steps to safeguard cultural property; ${ }^{10}$ and (ii) belligerents would protect their own cultural property (for example, by not exposing it to hostile fire),

6 The vast majority of authors writing about this topic criticize the existing international legal regime for being too lax. See, for example, Jeanette Greenfield, The Return of Cultural Treasures 257-61 (Cambridge 2d ed 1996); Patrick J. O'Keefe, Trade in Antiquities: Reducing Destruction and Theft 103-05 (UNESCO 1997). A few dissenters will be noted below.

7 Convention Respecting the Laws and Customs of War on Land (1907), art 27, 36 Stat 2277 (1910).

8 Id, art 56.

9 Hague Convention (cited in note 5).

$10 \mathrm{Id}$, art 3. 
refrain from targeting cultural property except in case of military necessity, and protect cultural property from vandalism and theft. ${ }^{11}$ Other provisions required parties to give appropriate training to their soldiers and to impose criminal punishments on people who violate the Hague Convention. A protocol further required occupying powers to prevent people from removing cultural property from occupied territory. ${ }^{12}$ A second protocol, ${ }^{13}$ signed in 1999, provided clearer and more detailed obligations, created several international crimes relating to the mistreatment of cultural property, extended the protections to internal conflicts, and created a committee with responsibility for administering the treaty regime. ${ }^{14}$

One-hundred sixteen states have ratified the 1954 Convention as of $2006 .{ }^{15}$ Ninety-three states have ratified the First Protocol ${ }^{16}$ and forty-four states-most of them small or poor-have ratified the Second Protocol. ${ }^{17}$

The conventional wisdom appears to be that the treaty regime has failed in its purpose to limit the destruction of cultural property. "Failure," however, is an ambiguous term, and we can distinguish several different meanings.

One indication of failure is simply that cultural property continues to be destroyed during wartime. Examples include the destruction of cultural objects during the Iran-Iraq war, the first Gulf War (when Iraq looted and destroyed Kuwaiti Museums), and the Yugoslav civil war. Belligerents did not merely fail to prevent looting; they engaged in looting and destruction as a war strategy. Peacetime destruction of cultural property, such as the famous depredations of the Taliban against Afghan cultural property, also occurred. ${ }^{18}$ Another indication of failure is that even the relatively light peacetime obligations-involving

$11 \quad \mathrm{Id}$, art 4.

12 Protocol to the Convention for the Protection of Cultural Property in the Event of Armed Conflict (May 14, 1954), 249 UN Treaty Ser 358.

13 Second Protocol to the Hague Cultural Property Convention of 1954 (Mar 26, 1999), 38 ILM 769.

14 For a lucid overview, see Patrick J. Boylan, The Concept of Cultural Protection in Times of Armed Conflict: From the Crusades to the New Millennium, in Neil Brodie and Kathryn Walker Tubb, eds, Illicit Antiquities: The Theft of Culture and the Extinction of Archaeology 64-86 (Routledge 2002).

15 For a list of state parties, see <http://erc.unesco.org/cp/convention.asp?KO=13637\& language $=\mathrm{E}>$ (visited Apr 21, 2007).

16 For a list of state parties, see <http://erc.unesco.org/cp/convention.asp?KO=15391\& language $=\mathrm{E}>$ (visited Apr 21, 2007).

17 For a list of state parties, see <http://erc.unesco.org/cp/convention.asp?KO=15207\& language $=\mathrm{E}>$ (visited Apr 21, 2007).

18 Kanchana Wangkeo, Monumental Challenges: The Lawfulness of Destroying Cultural Heritage during Peacetime, 28 Yale J Intl L 183, 243-51 (2003). 
marking cultural property and preparing storage sites in advance of war-seem to enjoy only limited compliance among secure and peaceful states. ${ }^{19}$

None of this proves that the Hague regime has had no effect, but if it has had an effect, it has been quite limited.

\section{The Peacetime Trade in Illegal Antiquities}

Cultural property is not always moveable-it includes buildings, for example-but moveable cultural property can be, and frequently is, exported. States generally permit owners of recently produced cultural property to sell and export it, but most states restrict ownership and export of antiquities. Despite these restrictions, there is a flourishing international market in exported antiquities, driven by the demand of museums and private collectors. To meet this demand, ordinary people-not archeologists-remove antiquities from the ground or wherever they are located, and sell them to smugglers, who in turn sell them to international dealers. The removal of the items is usually not done carefully, with the result that the item removed or items left behind may be damaged. Furthermore, removal rarely conforms with archeological norms, with the result that important contextual information is lost. In extreme cases, looters may break items into pieces because fragments are more easily concealed and transported than unbroken items and are valued by buyers despite the damage done to the original items.

The illegal trade in antiquities thus produces a number of harms. First, the antiquities are frequently damaged. Second, scholarly information is lost because archeological norms are violated. Third, the origin country loses the antiquities to foreign countries, which many people find objectionable for reasons that I will discuss below. Fourth, purchased antiquities usually disappear into private collections and cannot be studied by scholars or appreciated by people who care about cultural property.

Concerns about the illegal trade in antiquities have existed for decades. The origin states, which were often poor countries with weak institutions, could do little to prevent looters from extracting antiquities and sought assistance from the wealthy states to which the antiquities were exported. Prior to the UNESCO Convention, states generally prohibited the import and trade of stolen property, but did not prohibit the import of property in violation of export restrictions. Because of the difficulty of proving that the owner of an antiquity engaged in

19 See Patrick J. Boylan, Revien of the Convention for the Protection of Cultural Property in the Event of Armed Conflict (The Hague Convention of 1954) qा 5.37, 8.6 (UNESCO 1993), available online at <http://unesdoc.unesco.org/images/0010/001001/100159eo.pdf> (visited Apr 21, 2007) (noting limited peacetime preparation for protection of cultural property in war and 20 percent compliance rate in the issuing of reports). 


\section{Chicago Journal of International Law}

criminal behavior, domestic law did not provide any deterrent. ${ }^{20}$ The UNESCO Convention was intended to address the problem of the international antiquities market more directly by encouraging importing nations to prohibit importation of goods that were exported from origin countries in violation of export restrictions. Thus, the goods would not be permitted to cross the border.

One-hundred two states have ratified the UNESCO Convention, ${ }^{21}$ but conventional wisdom holds that the convention has failed to halt or erode the black market in illicit antiquities. ${ }^{22}$ One can point to a few local successes, but they have more to do with domestic politics and conditions than with the overall effectiveness of the treaty regime itself. ${ }^{23}$

\section{B. Why Have the TReaty Regimes Failed?}

Commentators have suggested several reasons why the treaty regimes have failed.

1. Existing Treaties Are Not Sufficiently Precise, or Do Not Have Strong Enough Language

Both the Hague Convention and the UNESCO Convention have vague language, and states can avoid the spirit of the instruments by asserting their compliance with the literal meaning of the words. For example, the Hague Convention obligated states to "respect" cultural property, without further elaboration. ${ }^{24}$ By contrast, article 7 of the Second Optional Protocol requires states to "do everything feasible to verify that the objectives to be attacked are not cultural property." The language of the Second Optional Protocol is stronger and more detailed. But few states have ratified the Second Optional Protocol.

This criticism may reflect some of the truth. All things equal, stronger obligations should result in greater cooperation. But all things are not equal. States clearly do not want to take on strong obligations; this is why 114 states have acquiesced in the vague Hague Convention, while only 44 states have

20 Paul M. Bator, An Essay on the International Trade in Art, 34 Stan L Rev 275, 285-89 (1982), reprinted in Paul M. Bator, The International Trade in Art 9-13 (Chicago 1983).

21 See UNESCO, List of the 102 States Parties, available online at <http://www.unesco.org/ culture/laws/1970/html_eng/page3.shtml > (visited Apr 21, 2007)

22 See John Henry Merryman, Two Ways of Thinking about Cultural Property, 80 Am J Intl L 831, 84849 (1986), reprinted in Merryman, Thinking about the Elgin Marbles 85-86 (cited in note 2); Greenfield, Retum of Cultural Treasures at 257-61 (cited in note 6).

23 The complex landscape has been surveyed in Greenfield, Retum of Cultural Treasures at 253-316 (cited in note 6 ) and many other works.

24 Hague Convention, art 4 (cited in note 5). 
consented to the Second Protocol. To understand why the treaty regime has failed, one must understand why states have not agreed to stronger obligations than those embodied in existing instruments that have been widely ratified.

\section{Existing Treaties Do Not Have Enough Parties}

As noted above, the Hague Convention has 116 parties but the Second Protocol has only 44 parties. The UNESCO Convention has 103 parties. The US is not a party to the Hague regime but does acknowledge it as customary international law. The US is a party to the UNESCO Convention. One might think that if more states joined these treaties, compliance with them would be more widespread.

The problem with this view is that existing parties do not take the treaty regimes seriously. If existing parties do not take the treaty regimes seriously, there is no reason to think that new parties would take them seriously either. As one indication of the problem, consider the Hague Convention's provision that requires states to provide reports to UNESCO that detail their compliance efforts. ${ }^{25}$ Although the provision is not obligatory, it is nonetheless striking that fewer than a quarter of parties have issued these reports, and the reports themselves in most cases describe at best perfunctory efforts to comply with the treaty regime. ${ }^{26}$ The UNESCO Convention obligates states to take steps to prohibit the illicit trade in antiquities, and yet no state invests significant resources in this effort. The US and Britain, for example, have only a handful of agents involved in prosecuting illegal traders and most countries have one or zero. $^{27}$

\section{Existing Treaties Do Not Have Strong Enough Enforcement} Mechanisms

Some treaties, such as the treaty that created the World Trade Organization, establish institutions that are supposed to administer the treaty and sometimes adjudicate treaty disputes. UNESCO has some power but not much. The Second Protocol creates a committee that is supposed to administer the Hague regime, but the committee has little power. Would a stronger international cultural property organization strengthen the treaty regime? Perhaps, but such an institution is not a realistic possibility. Very few effective international organizations exist because states are unwilling to trust international organizations to serve their interests. Similarly, it is difficult to imagine that states or international organizations like the International Criminal

\footnotetext{
25 Id, art 26.

26 See Boylan, Review of the Convention 98.6 (cited in note 19).

27 Matthew Bogdanos and William Patrick, Tbieves of Bagbdad 272 (Bloomsbury 2005).
} 
Court would devote significant resources to prosecuting looters and traders if violations of treaties were treated as international crimes, as many scholars advocate. $^{28}$

\section{Governments Do Not Have a Strong Interest in Committing to Protect, or Not to Harm, Cultural Property}

The vague language, the lack of ratifications, and the absence of a strong international organization reflect a deeper problem - that governments do not want to commit themselves to expend significant resources to protect foreign cultural property during wartime or peacetime.

This might seem surprising, given that governments have gone to the trouble of creating the two treaty regimes, that governments say that they care deeply about cultural property, and that governments clearly do care about their own cultural property. But governments have other priorities, and as international cooperation is difficult even when governments have strong and shared interests, it is not surprising that international cooperation to protect cultural property has been unsatisfactory.

The peacetime regime has failed because governments have mixed motives about the treatment of cultural property. The strongest proponents of export restrictions are mainly poor countries, which do not have enough resources even to police their own territory, and certainly do not have enough leverage internationally to compel wealthy states to prosecute illegal traders. Within the wealthy states, museums, traders, and collectors want to keep the trade in antiquities alive, and they pressure the government to reject strong international obligations to shut down the trade. Thus, the wealthy states have been lukewarm about protecting foreign cultural property, although they do protect their own. ${ }^{29}$

The wartime regime has failed in part because some governments have a policy of destroying the cultural property of the enemy. Thus, armies and paramilitary groups during the Yugoslav civil war targeted cultural property of the enemy in order to demoralize the local population and drive it off desired territory.

Even well-meaning governments find themselves unable to protect cultural property during wartime. Consider the recent events in Iraq. Although the US is not a party to the Hague regime, it has said that it regards that regime as customary international law, and it also clearly had no interest in destroying

28 See, for example, Andrea Cunning, The Safeguarding of Cultural Property in Times of War \& Peace, 11 Tulsa J Comp \& Intl L 211 (2003).

29 Some governments, such as the Taliban government in Afghanistan, deliberately destroy their own cultural property for ideological and political reasons. Foreign states cannot, as a practical matter, intervene. 
Iraq's cultural property. Some have argued that the widespread looting and destruction of Iraq's cultural property in the aftermath of the American invasion would not have occurred, or would have been minimized, if the US had ratified the Hague Convention and one or both of its protocols, or if more elaborate international treaties protecting cultural property had been in place. This does not seem correct. The looting of Iraq's cultural treasures in the aftermath of the American invasion was not caused by a defect in international law. The US, as an occupying power, had a general international legal obligation to maintain law and order in Iraq, and this general obligation included the specific obligation of preventing theft, whether of antiquities or of automobiles. The US tried to do so, but failed because it did not have enough forces in place, could not afford to muster additional military forces, and underestimated the problems of law and order that would occur in the wake of the invasion. The problem was not just looting of cultural property; it was looting of everything —office furniture in government buildings, inventories of warehouses and retail stores, cars, wiring, books, factory equipment, and so on. America's priority was protection of oil facilities, whose revenues would be necessary for reconstruction, and whose destruction would cause another environmental disaster, as occurred when Saddam's army set ablaze Kuwaiti oil wells during the first Gulf War. The insurgency has made it impossible for the US to do more than provide the rudiments of security over the last several years.

It thus seems unlikely that the US would have prevented the looting of the Baghdad Museum and thousands of archeological sites if it had ratified a treaty obligating it to protect Iraq's cultural property. If treaty instruments had required the US to divert resources from general security, the protection of Iraqi ministries, and the reconstruction of sewage treatment plants, electric facilities, and oil pipelines, this would only have fueled the insurgency, and would surely have been considered intolerable by American officials and the Iraqis themselves. The US would have gone ahead and violated these treaties with the approval or indifference of most of the world. Diversion of military and economic resources to protect cultural property would most certainly not have that effect if the consequence was anarchy and civil war, which would surely have hastened the destruction of Iraq's cultural property.

\section{What IS SPECIAL ABOUT CULTURAL PROPERTY?}

The assumption that cultural property is special, and therefore deserving of special legal protection, is so deeply ingrained that the question, "What is special about cultural property?," might seem silly. To see that the question is not silly, consider the reaction of local populations after the collapse of communist rule in Eastern Europe and the Soviet Union-they tore down the statues of 
communist heroes such as Lenin and Stalin. This reaction repeated itself after the US invasion of Iraq, when Iraqis tore down statues of Saddam. ${ }^{30}$

Thus, it is clear that not all cultural property is valuable to the citizens of origin states, only some is. How does one tell the difference between valuable and valueless cultural property? One might try to rely on objective aesthetic or scholarly criteria applied by experts, but one could hardly have demanded that Polish or Hungarian citizens not tear down aesthetically valuable statues of communists while permitting them to tear down the aesthetically objectionable statues. Such a judgment would make a mockery of the symbolic behavior of the crowds - to express their repudiation of the communist legacy.

A starting point is that cultural property, like any other form of property, is valuable to the extent that people care about it and are willing to pay to consume or enjoy it. If cultural property is "normal" property, then there is no reason to regulate it, or to treat it as different from other forms of property. In an unregulated market, the people who value it most will buy it. If a great many people value it, then we might observe what we in fact observe in many settings-museums purchasing the most valuable cultural property and showing it to numerous people for a fee. In a similar way, we have a mostly unregulated market in modern artworks. Some art is purchased for private collections, but most ends up in museums or in shows where the general public may see it.

Against this baseline, is there any reason to think that cultural property should receive special treatment? A number of theories have been proposed; the two that seem to be most influential are as follows.

\section{A. BOND With THE Past}

The most influential idea is that a particular people has a right to possession of its cultural property because possession of cultural property is important to the dignity of a people. ${ }^{31}$ There are several difficulties with this argument, however. First, it is not clear what it means for a "people" to "possess" cultural property. In practice, proponents of this idea mean that the cultural property should be stored in museums located in the territory of the state in which the people live, but why should this satisfy the requirement of possession? Is it necessary for the people to be able to see the cultural property? What if, as a practical matter, a state can only store its cultural property, or most of it, in warehouses, or must leave it in the ground? Is it sufficient if some (or

30 See Lior Jacob Strahilevitz, The Right to Destroy, 114 Yale LJ 781, 825 (2005).

31 For an argument roughly to this effect, see Patty Gerstenblith, Identity and Cultural Property: The Protection of Cultural Property in the United States, 75 BU L Rev 559 (1995). 
many) people in the relevant population own the cultural property and keep it stored in their houses?

Second, many local populations do not value cultural property. If people in a particular culture simply do not value artifacts from the past, should they nonetheless be required to store them in museums? Should they be forbidden to destroy them? As noted above, it seems odd to say that citizens of Poland had an obligation to preserve statues of communist leaders. The history of iconoclasm is long; are all iconoclastic movements to be condemned because they destroy cultural property?

Third, the moral basis of the "bond with the past" idea is also obscure. Iraqis today have little in common with the people who lived in Mesopotamia thousands of years ago. Much the same can be said about the people living in Greece, Italy, and India. Massive migrations have ensured that ancestral lines have been broken; the people who live in Italy today are descendants of people who lived in northern Europe or Asia. Most of the descendants of the ancient Greeks probably live in Turkey and other parts of western Asia. Of course, even if people could show that their ancestors produced cultural property they claim today, it is far from clear that they have a moral claim to the property. After all, the ancestors may have sold the cultural property, or thrown it away, or abandoned it. But in the absence of even this type of claim based on ancestry, the moral basis of a modern people's claim to cultural property is questionable. ${ }^{32}$

One might respond that, at least, a people should possess cultural property that was produced by their ancestors. But this response illustrates the oddness of the "bond with the past" argument. Consider modern cultural property-say, artworks that are being produced by living artists. No one believes that a painting finished yesterday by an American artist should stay in America, and be imprisoned in an American museum, on the grounds that American cultural property should stay on American soil. Although the painting is not (yet) part of our past, it will be part of our past in the future, but by then it might be lost to a private collector in Tokyo or London. This possibility does not seem to bother anyone. People have a strange set of intuitions, according to which local art should be bought and sold, and exported to other countries, where its presence can only honor our country; but as time passes, the people who happen to live in the geographic area where the art was produced, but have no relationship with the artist or the artist's descendants, have a stronger and stronger claim on the art, so that at some point they are justified in demanding its return.

32 Kwame Anthony Appiah, Whose Culture Is It?, NY Rev of Books 38, 38-39 (Feb 9, 2006); Merryman, 80 Am J Intl L 831 (cited in note 22). See also Bator, 34 Stan L Rev 275 (cited in note 20). 


\section{Chicago Joumal of International Law}

The only explanation I can see for this phenomenon is that people make a moral error: they anthropomorphize peoples. At some point, the art ceases to belong to a particular person (the artist, the buyer, the subsequent buyer, and so on) and starts to belong to a people (the population occupying the territory on which the artist lived, or related ethnically or racially to the artist). As time passes, the people's claim strengthens and any particular person's claim weakens. If this is the correct description of human psychology, it nonetheless is difficult to defend on moral grounds. The current possessor has a strong claim if he or she purchased the artwork (rather than stole it, in which case the victim would have the strong claim). If the people have a strong enough psychological need for the artwork, they can always purchase it through a government or museum. They do not have any moral right to possession.

Fourth, a related idea is that a people should have access to their cultural property so that they can learn about their history or, I should say, the history of the peoples who lived on the territory that they now occupy. The educational value of cultural property is similar to its scholarly value, which I will discuss below. It is sufficient to point out here that the educational value can be exploited without strict regulation of cultural property. Photographs and models will often be sufficient for the purpose of education, so it seems doubtful that the educational importance of cultural property justifies a prohibition on trade or export. International treaties could provide that institutional owners of cultural property like museums and governments should arrange for periodic traveling exhibitions.

\section{B. Cultural Property Has Scholarly Value and DEPENDS ON CONTEXT}

Cultural property has two features that distinguish it from other natural resources such as oil. First, it has scholarly and aesthetic value. It provides a window into the past and often (but not always) has intrinsic artistic merit. Second, its scholarly and aesthetic value depends greatly on its careful handling. When antiquities are removed from archeological sites, care must be used so that their context is understood and recorded, and the object itself is not damaged.

Modern artworks also have cultural value and many of them have scholarly value. Yet they may be bought and sold on the market; with limited exceptions, the owner of an artwork has the right to store and transport it without taking adequate care, to damage, or even destroy it. It is wrong to say that it is a matter of indifference to the world when the owner of valuable art does not properly care for it because people clearly do care about the treatment of artworks, even artworks they never see. But there is good reason to think that the art will flourish in a free market to a much greater degree than in a controlled market that restricts buyers' ability to dispose of their purchases however they see fit. 
When people are not constrained, there is greater demand for art, which pulls more artists into the market. Because people care about the art they purchase, they usually take care of it. And when art is significant enough on cultural grounds, it will usually be purchased by, or given to, museums. The market is not perfect, but seems to work well enough.

Is there any reason to think that the cultural and aesthetic value of cultural property justifies regulation of the cultural property market? Archeologists worry that in an unregulated market, people will extract cultural property from the earth without taking care to prevent damage, and without recording the contextual details, and so forth. They fear that traders will break apart large objects because the public has a fetishistic desire for old things and prefer fragments to nothing at all. And they fear that valuable antiquities will disappear into private collections, where they will be unavailable for public and scholarly inspection.

All of these concerns are justified, but they seem no more justified than the fear that people will buy valuable artworks and then damage them. This happens, but it does not happen as much as one might fear precisely because undamaged art is worth more than damaged art. Similarly, we should consider the possibility that antiquities are treated poorly today because they are so heavily regulated. Looters fear detection by the police; that is why they remove antiquities without taking care. If it were legal to remove cultural property and sell it, then professionals would take over and use care because antiquities are worth more when their provenance is known and when they are undamaged.

We should also expect cultural property to remain available for public and scholarly inspection to the same extent that modern art is. Many products will be purchased by private collectors, but many will also be purchased by museums and put on public display. Like the case of modern art, private purchasers of cultural property will lend it to museums and even donate it for tax benefits or for altruistic reasons. If the market were legal, then light forms of regulationfor example, the requirement that sales of cultural property be recorded-could ensure that antiquities are not lost, so that scholars could ask current owners for permission to study the object in question, and museums would be able to track down objects that they would like to purchase.

In sum, no one has provided a convincing argument that cultural property should be treated differently from art, oil, and other cultural and natural resources. An unregulated or lightly regulated market in cultural property would look like these other markets. A lightly regulated market might be justified because of some of the special features of cultural property; in particular, recording requirements may be justified. 


\section{THE LAWS OF WAR}

The laws of war have long required belligerents to avoid causing unnecessary damage to property-private or public-that does not have a military function, or is not used by opposing forces during hostilities. The laws also require occupying powers to maintain law and order among subject populations, and this, of course, means preventing looting, punishing theft, and so forth. We can think of these laws as providing a baseline of respect for property in general.

As we have discussed, cultural property is not different from property in general. It has special features, but so do all forms of property; none of these features suggest that cultural property deserves greater protection under international law than ordinary property does. Thus, the 1954 Hague regime, which does enhance international protection of cultural property during wartime, poses a puzzle. What function might it have?

Let us consider this puzzle from a practical perspective. A belligerent seeks to win a war. To win the war, it must destroy the military assets of the enemy. Most belligerents do not want to destroy civilian property when doing so can be avoided. There are two related reasons for this. First, belligerents often rely on the goodwill of the inhabitants of occupied territory. Goodwill is most cheaply purchased when the belligerent enforces law and order and restrains its own forces from abuses. Second, belligerents will often want to exploit local resources for their own purposes.

These belligerents have limited resources, and must decide how they should be used to protect nonmilitary property. Suppose, for example, that the belligerent must choose between using soldiers to protect an oil well or to protect an archeological site-which should it protect? If left to its own devices, the belligerent will protect whichever property is worth more. By doing so, it maximizes the goodwill of the civilian population, and its own ability to exploit local resources.

It is possible, of course, that the local population will care more about the cultural property than about the oil, but if this is so, the belligerent has every incentive to take account of the population's views.

Not all belligerents are so benign. Some belligerents do not seek to mollify the local population but to drive it off the land. We saw an example of this phenomenon in the Yugoslav civil war. Belligerents targeted cultural property; they did not target natural resources. Presumably, the reason was that they expected to exploit the natural resources for their own benefit, but placed no value on the cultural property, and instead believed that destroying it would make clear to the local population that it was expected to leave.

In this situation, special international protection of cultural property is easier to understand. Such a regime attempts to solve the problem that a 
belligerent may place less value on the cultural property than its intrinsic worth, as measured by the market or by the sentiments of the people who care about it.

However, for several reasons the view that international humanitarian law can ensure meaningful protection of cultural property in war zones is implausible. First, consider the general rule that belligerents should respect civilian property. Relatively benign states that seek to control, rather than cleanse, local populations have the right incentives to comply with that rule, and to give as much priority to cultural property as its value justifies relative to other considerations, such as protection of ordinary private and government property, maintaining order, and so forth. A stronger rule that required the benign states to protect cultural property would not improve their incentives and could, conceivably, interfere with the desirable allocation of resources by forcing states to protect cultural property more than other types of property that are more important or valuable. Meanwhile, malevolent states or governments that seek to engage in ethnic cleansing will not pay attention to international law protecting cultural property. After all, if they are already violating laws against genocide and crimes against humanity, they are not likely to pay attention to the Hague Convention and its protocols.

Second, even if we confine our attention to the relatively benign, lawabiding state, it is far from clear what it would mean for a treaty to require a belligerent to give enhanced protection to cultural property. As noted above, the general laws of war already prohibit belligerents from targeting, and failing to protect nonmilitary property. Stronger rules that force belligerents to devote more resources to protecting cultural property, so that cultural property received greater protection relative to, say, oil facilities would be extremely difficult to draft. A rule that prohibited states from targeting cultural property even in cases of military necessity would not be accepted. A rule requiring states to protect all cultural property is not practicable-the US simply could not have protected all ten thousand archeological sites in Iraq. A rule requiring the belligerent to devote "substantial" resources to protecting cultural property, or protecting cultural property when doing so is "feasible," would leave the belligerent with the same amount of discretion that it has under the general rule.

Third, states enter treaties and comply with them only when they have an interest in doing so, and this can exist only when there is the possibility of a quid pro quo. Belligerents agree to treat captured soldiers in a humane fashion only in order to induce the enemy to treat their POWs humanely as well. ${ }^{33}$ Here, we must imagine that belligerents would agree to respect enemy cultural property in return for the enemy's promise to respect the belligerent's cultural property. In principle, a deal is possible; in practice, history has shown that belligerents just

33 For a discussion, see Eric A. Posner, Terrorism and the Laws of War, 5 Chi J Intl L 423 (2005). 
do not value their own cultural property enough to be willing to make this type of deal. Major military powers-say, the US, China, Russia, and India-know that they might want to intervene in another country and are not willing to submit to significant constraints on military discretion. Smaller, archeologically rich countries enter these treaties but never expect to engage in military interventions in other countries, so the treaties do not work as meaningful constraints. Thus, the military powers gain little from entering into these treaties, and that is why the Hague Convention has such weak language, few states have entered the Second Protocol, and compliance has been limited in any event.

In sum, the justification for laws of war that protect cultural property is weaker than ordinarily recognized. Generally law-abiding belligerents have the right incentives to protect cultural property; laws requiring special protection for cultural property could only reduce their ability to control territory. Generally illdisposed belligerents have the wrong incentives, and laws requiring special protection for cultural property are unlikely to improve them.

\section{THE UNESCO CONVENTION}

The UNESCO Convention encourages states to respect export restrictions imposed by origin states. To understand the purpose of this instrument, suppose that an origin state such as Italy or Mexico has no export restriction but does make it a crime to remove and sell antiquities taken from private or government property. A person who loots an archeological site and sells it to an international trader commits the crime, and the trader is probably guilty as well. If the trader is not caught and exports the antiquity to a recipient state such as the US or Switzerland, then the trader is likely guilty of dealing in stolen property in the recipient state, and so may be a national of the recipient state who buys the antiquity. But as a practical matter, it is unlikely that either the trader or the buyer will be prosecuted under the criminal law of the recipient state. The government of the origin state would need to inform the recipient state of the suspected theft, but the government is unlikely to know about it. Even if it did, it will be difficult for law enforcement of the recipient state to track down the stolen object, and the law enforcement officials are unlikely to be willing to spend significant resources doing so. Then it will be difficult to prove beyond a reasonable doubt that the trader or the buyer knew that the property was stolen-witnesses and records, if any, will be in the origin state. For all these reasons, prosecutions for theft of antiquities in recipient states remain unusual.

Suppose now that the origin state creates export restrictions. This alone will have little effect on the problem. The export restriction prohibits the trader from exporting the antiquities; this means that border control agents of the origin state might search people's luggage for antiquities and confiscate them if they are found. But borders are porous, and most often smugglers will be able to 
find a way around border control agents or will be able to bribe them. The recipient state's border agents will not confiscate the antiquities if they find them; they have no obligation to do so.

The function of the UNESCO Convention is to encourage the recipient state to pass laws directing border control agents to confiscate goods whose importation violates the export restrictions of the origin state. The recipient state's border control agents are likely to be better trained, more numerous, and less easily bribed than the origin state's agents, because origin states tend to be poor (Italy is an exception) and recipient states tend to be wealthy. The recipient state will not necessarily prosecute the trader but it will confiscate the antiquities and return them to the government of the origin state.

The extra layer of border control no doubt deters smuggling at the margin, but there is no systematic evidence that the effect is significant (there is a little anecdotal evidence), and the general view is that the illegal market in antiquities is worse today than it was in 1970 . It may be that recipient states just do not care enough about the illegal antiquities trade to put the necessary resources into stopping it. What is true is that enforcement is significant enough that there is a black market, which means that the trades are hidden from view.

The current international approach to the market in antiquities is illadvised. Calls for greater investment in law enforcement ${ }^{34}$ would, if heeded, only make things worse. Rather than creating an artificial black market, states should try to create a legal market which could then be lightly regulated in order to correct some of the problems of the antiquities market.

To reach this goal, the recipient states should stop respecting the export restrictions of origin states, and should encourage origin states to eliminate export restrictions and decriminalize the ownership and trading of antiquities. (Many states do allow some ownership and trade, but usually not of the most valuable objects.) Some recipient states may willingly change their rules, given that existing rules seem to have little effect. Others may change their rules if they receive aid or assistance. As I discuss in more detail below, some of the features of a legal market should be attractive to origin as well as recipient states.

This system would have several advantages. First, a legal market would be more transparent than the existing black market. Traders would have no reason to hide their identities; owners would be more willing to publicize their ownership in order to attract buyers. As a result, scholars would have less trouble tracking down antiquities they wish to study, and governments that would like to buy valuable cultural property would have less trouble finding it. If the market were legal, then prospectors could extract cultural property from the

34 See, for example, Bogdanos and Patrick, Thieves of Baghdad at 272 (cited in note 27). 
soil in the open, more slowly, in daylight, with more care, and with more attention to context. Because antiquities are more valuable when their provenance is known, prospectors would be more likely to hire professional archeologists to remove and record objects, and verify their identity. This would add to the sum of knowledge, improve scholarship, and improve the handling of antiquities. ${ }^{35}$

Second, if the market were legal, then trade in antiquities could be subject to taxation and limited regulation. I will address regulation below. Taxation is of great importance because many origin states are extremely poor. In addition, the foreign exchange used to purchase antiquities could be used to purchase needed goods from abroad.

Third, one of the benefits of a free market in cultural property is that much cultural property would leave poor, insecure states that suffer from war, corruption, and inefficient law enforcement, and be stored in wealthy, secure states. In their self-interest, commercial firms would remove cultural property from war zones and potential war zones, and of course eventually most cultural property would be sold to museums and private collections located in secure, first-world countries. If the contents of the Baghdad Museum had been owned and held by museums located in New York, Tokyo, London, or Chicago, they would never have been stolen or destroyed during the second Gulf War.

As noted above, the market need not be wholly unregulated, as long as the regulations are not so severe as to recreate the incentive to smuggle. Regulation could serve several purposes. It could require that prospectors and traders record their transactions and place the record in public files. It could create minimum standards of care in the extraction, preservation, transportation, and storage of antiquities. To address the educational aspects of cultural property, states could agree that recipient states would, from time to time, fund loans from museums and private collectors back to origin states for limited periods of time.

\section{CONCLUSION}

There is no point in pretending that deregulating the international market in cultural property is a panacea. There would be many abuses and frustrations. Much cultural property would disappear into private collections, of course; much would be damaged as a result of careless handling; and origin states will continue to be frustrated that "their" cultural property is scattered around the globe. Part of my solution is just to define away the problem by way of a claim that origin states do not have a strong moral right to the cultural property created by predecessor populations. But this is another way of saying that the

35 See Merryman, Two Ways of Thinking about Cultural Property at 86-87 (cited in note 22). 
goals of the current regime are not justified; and if the goals are not justified, or have a weak justification, then all the damage created by the current regime is inexcusable.

The current regime may well have been motivated by outrage on the part of origin states, and guilt on the part of recipient states, that so much property really has been stolen from recipient states-that is, looted by western armies or explorers, rather than purchased. These are historical controversies that I do not address. But whatever the motivation of the current regime, one must recognize that its flaws result from its fundamental assumptions rather than from technical problems that could be corrected through marginal reform. 